\title{
Biografia edukacyjna i jej osobliwości - studium jednego przypadku
}

\begin{abstract}
Streszczenie: Artykuł stanowi przykład analizy biografii edukacyjnej jednego przypadku. Poszukiwaniom autorki towarzyszyło pytanie o osobliwości tej biografii, jej specyfikę i charakter. Za podstawę analizy przyjęto koncepcję trajektorii Fritza Schützego i Gerharda Riemanna, próbując ukazać edukacyjny potencjał cierpienia ludzkiego.
\end{abstract}

Slowa kluczowe: biografia, trajektoria, cierpienie, edukacja.

\section{Educational biography and its singularity - the single case study}

Summary: This text is an example of the analysis of the educational biography of one case. The author is trying to show originality of this biography, the specificity and nature. Based on the concept of trajectory Gerhard Riemann and Fritz Schütze, trying to show the educational potential of human suffering.

Keywords: biography, trajectory, suffering, education.

\section{Wprowadzenie}

Podstawą niniejszego tekstu stał się wywiad, który przeprowadzony został w ramach projektu Grundtvig Partnership Project No 2010-1-PT1-Gru06-051166 „Lives in Changing - a Multicultural Approach of Initial Expectations (the before), Learning Process (the during) and the Final Outcomes (the after)" - Butterfly

${ }^{*}$ Uniwersytet Łódzki, Wydział Nauk o Wychowaniu, Zakład Andragogiki i Gerontologii Społecznej, 91-408 Łódź, ul. Pomorska 46/48; annagc@tlen.pl 
- projekt partnerski Grundtviga, dotyczącego funkcji procesu uczenia się dorosłych w sytuacji zmian życiowych, realizowanego przez pracowników Zakładu Andragogiki i Gerontologii Społecznej Uniwersytetu Łódzkiego.

Artykuł stanowi przykład analizy biografii edukacyjnej jednego przypadku. Poszukiwaniom autorki towarzyszyło pytanie o osobliwości tej biografii, jej specyfikę i charakter. Za podstawę analizy przyjęto koncepcję trajektorii ludzkiego życia Fritza Schützego i Gerharda Riemanna.

\section{Trajektoria cierpienia}

Zgodnie z definicją zawartą w Słowniku wyrazów obcych trajektoria to krzywa zakreślana przez poruszający się $\mathrm{w}$ przestrzeni obiekt, który poddawany jest zewnętrznym siłom (Sobol, 2002, s. 1120). Pojęcie to stosowane jest w różnych dziedzinach naukowych, a koncepcję trajektorii początkowo wykorzystywano głównie do opisu procesu umierania. F. Schütze i G. Riemann rozszerzyli to podejście i wykorzystali do analizy różnorodnych ludzkich problemów. Jak pisze Elżbieta Zakrzewska-Manterys, tak rozumiana trajektoria odnosi się do „badania procesów nieuporządkowanych, nieustrukturyzowanych, chaotycznych, a jednocześnie przysparzających uczestniczącym w nich osobom cierpienia i bólu [...]. W tym więc ujęciu trajektoria zawsze dotyka cierpienia i użyta być może jako swego rodzaju metodologiczna pomoc w opisywaniu i badaniu radzenia sobie z cierpieniem" (Zakrzewska-Manterys, 1995, s. 41).

Stephen Hawking powiedział, że wszechświat ma nie tylko jedną historię, ale całą gamę możliwych historii. Te historie mogą być podobne do siebie w dużej skali, ale znacznie różnią się między sobą w skali normalnej codzienności. Biografia jest pewnym faktem empirycznym i jednocześnie kategorią teoretyczną (Giza, 1990). W życiu pojedynczego człowieka to, co spostrzegane jest jako odrębne sfery życia osobistego czy społecznego, staje się integralnym składnikiem jego biografii (Lindyberg, 2012, s. 12). Na te składniki składają się sekwencje doświadczeń i zachowań człowieka w konkretnych sytuacjach, w jakich się on znajduje od narodzenia aż do śmierci (Dobrowolska, 1992, s. 75-85).

Wydarzenia życiowe ${ }^{1}$ obecne w biografii każdej jednostki mogą mieć charakter wydarzeń przełomowych, czyli takich, które w życiu danej osoby wywarły na nią szczególny wpływ, na przykład zmieniły bieg jej życia czy tożsamość. Niektórym wydarzeniom przełomowym może towarzyszyć cierpienie. Kształtuje ono indywidualne biografie i może zmieniać stosunek doznającej go jednostki do

${ }^{1} \mathrm{~W}$ literaturze traktującej o biografii często używane są także takie pojęcia, jak „,wydarzenia krytyczne” czy „zdarzenia życiowe”. Według M. Przetacznik-Gierowskiej, to punkty graniczne nadające pewien kierunek różnym aspektom życia człowieka (1995, s. 7). Natomiast M. Nowak-Dziemianowicz w pojęciu „zdarzenie krytyczne” podkreśla pewien zwrot w losach osoby, który, mimo naznaczenia cierpieniem, może stać się okazją do emocjonalnej dojrzałości i zyskania nowych kompetencji (2006, s. 229). 
siebie i do świata. Charakterystyczne dla trajektoryjnych procesów cierpienia jest to, że wnoszą w życie przeżywających je ludzi poczucie nieubłaganego losu oraz że zmuszają je do postrzegania siebie jako jednostek kontrolowanych przez obce, zewnętrzne siły, na które nie ma się wpływu (Lindyberg, 2012, s. 18). W myśl koncepcji Schützego i Riemanna postępowanie człowieka w obliczu cierpienia jest uzależnione od jego subiektywnego odczuwania i interpretowania zaistniałej sytuacji życiowej. Nie musi on biernie poddawać się sytuacji, może podjąć wysiłek ukierunkowany na nadanie cierpieniu sensu, a nawet wartości (Okła, 2009; Mazurek, 2011, 2013). W obliczu cierpienia człowiek jest zdolny do odszukania w sobie, w swoim otoczeniu zasobów i wykorzystania potencjału, który tam tkwi.

Jak wspomniano wyżej, podstawą analizy materiału narracyjnego uczyniono koncepcję trajektorii losu ludzkiego F. Schütze i G. Riemanna. Według tych autorów każda trajektoria przebiega zgodnie z określoną sekwencyjnością:

- stopniowe gromadzenie się potencjału trajektoryjnego,

- przekroczenie granicy uczynnienia potencjału trajektoryjnego,

- próba osiągnięcia i rozwinięcia chwiejnej równowagi radzenia sobie z życiem codziennym,

- destabilizacja chwiejnej równowagi i radzenia sobie z życiem codziennym,

- załamanie się organizacji życia codziennego i orientacji wobec samego siebie,

- próby racjonalizacji trajektorii i pogodzenia się z nią,

- praktyczna praca nad trajektorią i uzyskanie nad nią kontroli oraz/lub uwolnienie się z jej więzów (Schütze, 1997, s. 25-27).

Koncepcja ta posłużyła autorce do analizy biograficznych mechanizmów rozwijania się cierpienia i wpływu tego cierpienia na tożsamość osoby doświadczającej go. Przedmiotem rozważań uczyniono trajektorię cierpienia związaną z macierzyństwem. Macierzyństwo, ze względu na wagę tego doświadczenia, może być często wydarzeniem przełomowym². Zazwyczaj bowiem pojawienie się dziecka wiąże się dla kobiety z silnym przeżyciem psychicznym oraz z pewną zmianą stosunku do otaczającej ją rzeczywistości. Macierzyństwo bywa więc najczęściej istotnym wydarzeniem w biografii kobiety.

\section{Krótka charakterystyka badanej osoby}

Narratorka to 75-letnia kobieta, Teresa, samotnie mieszkająca wdowa, emerytowana nauczycielka, mieszkanka Łodzi. Legitymuje się wyższym wykształceniem, pracowała jako nauczyciel w szkole podstawowej i liceum

${ }^{2}$ Problematyką doświadczania macierzyństwa zajmowała się między innymi Bogusława Budrowska w pracy Macierzyństwo jako punkt zwrotny w życiu kobiety (2000) oraz Bogna Bartosz w pracy Doświadczanie macierzyństwa: analiza narracji autobiograficznych (2002). 
ogólnokształcącym, pełniła też funkcję metodyka-kuratora w Kuratorium Oświaty w Łodzi. Mieszka w skromnie wyposażonym dwupokojowym, niedużym mieszkaniu w wieżowcu. Ma odłączony gaz, nie ma telewizora, żyje bardzo skromnie i oszczędnie, utrzymując się z niewysokiej emerytury. Ma dorosłego, adoptowanego syna, który aktualnie odbywa karę więzienia. $\mathrm{Z}$ dalszą rodziną utrzymuje sporadyczne kontakty. Ma dobre, dość zażyłe relacje z sąsiadkami, również samotnymi kobietami w zbliżonym do jej wieku. Swój stan zdrowia określa jako zły. Jest osobą niewierzącą.

\section{Trajektoria macierzyństwa}

W analizowanym materiale badawczym odnaleziono niektóre ogólne cechy trajektorii, które poniżej przedstawiono w punktach:

1. Trwałe załamanie się oczekiwań - narratorka, będąc już wdową, podejmowała kilkukrotnie próbę adopcji dziecka. Za każdym razem były to 4-5 letnie dziewczynki, które po pewnym czasie pobytu u narratorki, kiedy to wywiązała się między nimi silna więź emocjonalna, $\mathrm{z}$ różnych powodów musiały wrócić do biologicznych rodziców lub instytucji. Rozstania z dziećmi wywoływały cierpienie i frustrację. Ostatnia próba adopcji powiodła się, nie wynikała jednak jedynie z potrzeb narratorki, ale także ze swoistego poczucia obowiązku. Narratorka wyjechała na obóz zorganizowany przez M. Łopatkową, którego celem były „aranżacje” adopcji. Badaną poproszono o opiekę (a w konsekwencji przysposobienie) najstarszego i najbardziej opóźnionego w rozwoju chłopca, uznając, iż jako nauczycielka jest najbardziej do tego predysponowaną osobą. Chłopiec, sierota społeczna mająca oboje rodziców i rodzeństwo, od pierwszych chwil pobytu w domu badanej sprawiał kłopoty - był mało samodzielny, nie radził sobie w szkole, uciekał, wymagał stałej opieki i wsparcia wielu specjalistów. Nie był też do końca akceptowany przez ojca narratorki, który tęsknił za wnuczką (jedną z dziewczynek, którą narratorka próbowała przysposobić). W wyniku łańcucha wzajemnie uwarunkowanych zdarzeń sprzyjających pojawieniu się trajektorii, doszło do narastającego załamania oczekiwań.

2. Podporządkowanie siłom zewnętrznym - narratorka nie radząc sobie na przestrzeni wielu lat $\mathrm{z}$ wychowaniem syna, zaczęła tracić poczucie kontroli nad własnym położeniem życiowym. Notoryczne ucieczki dziecka, jego dysfunkcjonalność, a w późniejszym czasie demoralizacja (w tym liczne kradzieże) i alkoholizm doprowadziły u badanej do poczucia „bycia popychaną” przez jakąś zewnętrzną siłę, której działanie nie było dla niej zrozumiałe. Ta siła z jednej strony popychała ją do aktywności mającej na celu pomoc synowi - często irracjonalną i nieuzasadnioną (narratorka „załatwiła” mu rentę inwalidzką, mieszkanie socjalne, prała, robiła zakupy, gotowała, mimo iż syn zaniedbywał mieszkanie, wyprze- 
dawał sprzęty, przepijał pieniądze), z drugiej zaś prowadziła do poczucia absolutnej zewnątrzsterowności, a w konsekwencji zamknięcia na własne potrzeby.

3. Konfrontacja z czymś nieuchronnym, nieznanym - w ocenie autorki była to konfrontacja z chorobą alkoholową i demoralizacją syna. Koncentracja uwagi narratorki została skupiona całkowicie na walce $\mathrm{z}$ tą chorobą. Poszukiwanie przyczyn alkoholizmu syna również w sobie samej, spowodowało załamanie się organizacji życia codziennego i orientacji wobec siebie. Nastąpiło uruchomienie strategii wycofania się z obszarów dotychczasowego życia, powodując tym samym zamknięcie się na siebie i innych ludzi.

4. Indywidualna dezorientacja - skutkująca psychicznym odizolowaniem od świata. Stan ten przejawiał się wyrwaniem narratorki - w pewnym przynajmniej stopniu - z normalnego toku spraw, ,z potocznego świata”. Tożsamość narratorki nie była przygotowana na zmierzenie się z biegiem wydarzeń i zaadaptowaniem do nowej sytuacji życiowej. Uwidocznione w tej fazie zostało przekreślenie postawy postrzegania samego siebie.

5. Biograficzni opiekunowie - jednym z nich była matka narratorki, z którą badana po śmierci ojca mieszkała, dzieląc trudy wychowania dziecka. W wypowiedzi narratorki jawi się ona jako osoba znacząca, istotnie zaangażowana w jej biografię. Badana ze świadomością podkreślała, iż wpojone przez matkę w procesie wychowania zasady wpłynęły na jej zachowanie w życiu dorosłym - zarówno w obszarze pracy zawodowej, jak i w sferze macierzyństwa. Jako biograficzny opiekun jawi się także znajoma narratorki - matka alkoholika - osoba w podobnej sytuacji życiowej (podobnie obciążona), dzięki której badana zaangażowała się w proces terapii dla rodzin osób uzależnionych od alkoholu (tzw. osób współuzależnionych).

6. Kumulatywny proces narastania bezładu - proces ów rozpoczyna się w momencie, kiedy syn okrada narratorkę, wynosząc z jej mieszkania nie tylko ostatnie cenne przedmioty, ale także przedmioty codziennego użytku, nie pozostawiając żadnych sztućców, garnków, kradnąc też ubrania, buty, pościel. To wydarzenie, brzemienne w skutkach do dziś, doprowadziło badaną do niemal skrajnej biedy i nasilenia objawów depresji. To był też moment przełomowy, kiedy to narratorka podjęła próbę zmiany - zgłosiła się do psychiatry i zaangażowała się w proces terapii dla rodzin osób uzależnionych.

Według twórców koncepcji trajektorii losu ludzkiego istnieją trzy możliwości wyjścia z cierpienia: ucieczka, systematyczne oswajanie się z trajektorią cierpienia oraz włączenie trajektorii do doświadczenia życiowego jako rozwojowego komponentu biograficznego. W przypadku pani Teresy wydaje się, że nie doszło jeszcze do opanowania potencjału trajektoryjnego. Narratorka jest aktualnie na etapie systematycznego oswajania się z trajektorią cierpienia, próbując włączyć ją w codzienność. Jednak widoczna jest także ucieczka od trajektorii - przejawiająca się w stanie swoistego paraliżu emocjonalnego, ucieczce w świat wspomnień i marzeń - życie jakby w dwóch światach - realnym (tu i teraz) i śnionym (światem fikcji związanym z przeszłością), w którym jest młodą, zdrową i szczęśliwą kobietą. 
Należy jednak zauważyć, że mimo iż narratorka nadal trwa w obciążonej trajektoryjnie tożsamości, podejmuje próby redukowania jej niszczącego wpływu poprzez uczestnictwo w różnych formach życia społecznego. Należy do Związku Emerytów i Rencistów i choć nie nawiązała tam silnych relacji towarzyskich, to korzysta z proponowanych tam aktywności kulturalnych - np. wyjścia do kina. Ponadto podjęła decyzję o wzięciu udziału we wspomnianym projekcie realizowanym przez Zakład Andragogiki i Gerontologii Społecznej Uniwersytetu Łódzkiego, w który zaangażowane były również osoby będące uczestnikami Uniwersytetu Trzeciego Wieku, co w efekcie poskutkowało tym, iż narratorka również aktualnie jest słuchaczką UTW.

\section{Trajektoria jako potencjał edukacyjny}

W biografii narratorki bardzo wyraźnie zarysowana została linia biografii edukacyjnej, najsilniej zaś linia edukacji formalnej. Jej etapy przebiegają od szkoły podstawowej do Uniwersytetu Trzeciego Wieku. Pani Teresa ukończyła liceum pedagogiczne w trybie dziennym, kolejne etapy realizowała zaocznie lub wieczorowo. Już w trakcie pracy zawodowej podjęła studia na Wydziale Matematyki UŁ. Była to decyzja przemyślana, wynikająca z zainteresowań narratorki. Jednak ze względu na brak wsparcia ze strony zakładu pracy oraz niemożność pogodzenia obowiązków zawodowych ze studiowaniem szybko zrezygnowała. Żal z powodu tej rezygnacji wybrzmiewa w wypowiedziach narratorki do dziś.

Kolejny etap edukacji - nauka w Studium Nauczycielskim na kierunku filologia rosyjska - podyktowany został sytuacją polityczną Polski, a w efekcie potrzebami szkoły, w której zatrudniona była narratorka. Wprowadzenie obowiązku nauczania w szkołach języka rosyjskiego spowodowało konieczność wykształcenia osób mogących realizować to zadanie. Pani Teresa, pod wpływem nacisków dyrekcji szkoły, wbrew swoim zainteresowaniom, podjęła się zdobycia kwalifikacji w tej dziedzinie. Kolejnym etapem była próba podjęcia nauki w Państwowej Wyższej Szkole Pedagogicznej w Krakowie na kierunku filologia rosyjska (studia zaoczne), gdzie jednak nie udało się narratorce zdać egzaminów wstępnych. W kolejnych latach, po utworzeniu kierunku filologia rosyjska na UŁ, narratorka ukończyła tu studia wieczorowe. Należy jednak zauważyć, że zakończenie tego etapu edukacji wymagało od narratorki wiele trudu, gdyż zbiegło się z ciężką przewlekłą chorobą i śmiercią jej męża. Pani Teresa jest także absolwentką studiów podyplomowych z zakresu organizacji i zarządzania na Uniwersytecie Łódzkim. Ten etap edukacji wynikał z podjęcia pracy w kuratorium. Ponadto narratorka ukończyła liczne kursy doszkalające, w tym wakacyjne, między innymi z zakresu nauczania w klasach I-IV.

Warty podkreślenia jest fakt, iż narratorka wszystkie etapy edukacji, w tym również edukacji pozaformalnej, może potwierdzić adekwatnymi dokumentami 
- świadectwami, dyplomami, certyfikatami, zaświadczeniami, traktując je jako dowody własnej sprawności intelektualnej i sukcesów zawodowych w przeszłości.

Aktualnie pani Teresa jest słuchaczką UTW - aktywność ta, niezwykle dla niej ważna, a będąca wynikiem uczestnictwa w projekcie, jest ewidentnym przejawem potrzeby uczenia się, rozwoju, potrzebą permanentnej walki z własną izolacyjną trajektorią.

Należy zauważyć, że linia biografii edukacyjnej narratorki jest wyraźnie wyznaczona przez określone sytuacje zewnętrzne - presję zwierzchników, sytuację polityczną państwa, sytuację rodzinną, natomiast decyzja związana z przystąpieniem do UTW jest w pełni świadomą, ,wewnętrzną” potrzebą kobiety.

Narratorka w swojej wypowiedzi dotyczącej edukacji odwoływała się jedynie do jej formy sformalizowanej. Widoczne jest więc wąskie rozumienie przez badaną pojęcia edukacja, które ograniczone zostało do uczestnictwa zinstytucjonalizowanego. Uczenie się narratorka utożsamia ze „szkolnym” procesem przyswajania wiedzy, tzn. czytaniem i powtarzaniem tekstu, aż do momentu zapamiętania. Jednak analiza materiału badawczego ujawniła obecność w biografii badanej trzech form edukacyjnych: nie tylko formalnej, pozaformalnej, ale także i nieformalnej. Ta ostatnia nie jest jednak przez nią uświadomiona, a obecna zwłaszcza w ostatnim okresie życia. Doświadczanie cierpienia, próba opanowania potencjału trajektoryjnego ,popychało” panią Teresę do swoistej aktywności edukacyjnej - np. systematycznie rozwiązywała krzyżówki, czytała czasopisma i książki wypożyczane z biblioteki, okazjonalnie chodziła do kina i teatru, uczestniczyła w terapii. Konieczność funkcjonowania w bolesnej rzeczywistości wywołała nieuświadomiony instynkt podjęcia trudu poradzenia sobie z zaistniałą sytuacją. Można więc tu mówić o tzw. milczącym uczeniu się - nieintencjonalnym i nieuświadomionym.

\section{Wnioski}

- $\mathrm{Na}$ funkcjonowanie społeczne narratorki, swoistą regresywność, silny wpływ wywarła trajektoria związana z macierzyństwem, co w konsekwencji spowodowało zmiany tożsamościowe, nie tylko osobowościowe, ale także społeczne, związane z deprywacją potrzeb i poczuciem niskiego statusu społecznego.

- W narracji uwidocznione zostały dwie perspektywy czasowe - przeszłość: etap sprawności psychomotorycznej i aktywności (zwłaszcza zawodowej) oraz teraźniejszość: etap postępującego regresu po przejściu na emeryturę - regresu w relacjach społecznych, funkcjonowaniu społecznym, funkcjonowaniu psychofizycznym oraz obniżenie statusu społecznego i materialnego.

- Zmiany, które zachodziły w życiu narratorki były w dużej mierze, w jej opinii, wynikiem zewnętrznych sytuacji czasowo-przestrzennych, które je spowo- 
dowały, nie zaś jej działalnością celową i świadomą. W narracji wyraźnie uwypuklony został stan emocjonalny kobiety - życie przeszłością, nostalgią za czasem sprawności fizycznej, intelektualnej, czasem sukcesów zawodowych, co wydaje się stanowić nadrzędny sens jej aktualnego życia.

- W analizowanym materiale silnie zaznaczona jest rozbudowana edukacyjna linia biografii zarówno w wymiarze formalnym, pozaformalnym, jak i nieformalnym - narratorka przez cały okres kariery zawodowej uzupełniała wykształcenie, doskonaliła umiejętności zawodowe, obecnie jest słuchaczką UTW. Ponadto uwidoczniono uczenie się nieformalne, choć przez badaną nieuświadomione i niezidentyfikowane.

-W materiale badawczym uwidoczniona została trajektoria izolacyjna - odczuwanie braku nadziei, opuszczenie, oddzielenie od rodziny i innych układów społecznych - autoalienacja. Wydaje się jednak, że aktualnie narratorka jest na drodze systematycznego wykorzystywania potencjału trajektoryjnego, pracy nad odzyskaniem kontroli, opanowaniem „bezładnych procesów” (Riemann, Schütze, 1992, s. 92).

- Narracja okazała się dla kobiety pewnego rodzaju katarzis - wywiad umożliwił badanej nie tylko wypowiedzieć swoje wspomnienia, emocje, zwerbalizować cierpienia, ale także dał możliwość zreflektowania sytuacji życiowej i określenia aktualnych potrzeb - w tym także edukacyjnych. Ta swoista podróż w świat osobistych przeżyć, pełna potyczek, barier, kryzysów i porażek pozwoliła narratorce skonfrontować się z tym chaosem i wypracować strategię poradzenia sobie z nim - przejawem tego okazała się decyzja o uczestnictwie w UTW.

\section{Osobliwości biografii edukacyjnej}

Zgodnie z definicją zawartą w Stowniku języka polskiego osobliwość to coś, co stanowi o wyjątkowości czegoś, o jego niezwykłości, niepospolitości i oryginalności; coś niepowtarzalnego, rzadkiego, niezwykłego i zadziwiającego; to unikat, fenomen, rzadkość. Analizując biografię człowieka, trudno określić, czy jakiś element ludzkiego życia należy uznać za „niezwykły” czy „zwykły”, albo „niepospolity” czy „pospolity”. Cierpienie ludzkie ma wiele odcieni, a każdy odcień wymaga osobnej historii, osobnej analizy, osobnej odpowiedzi na rodzące się pytania. Każdy odcień cierpienia jest niezwykły i zarazem zwykły, każdy jest osobliwością, w której daje się odnaleźć różnego rodzaju komponenty.

Biografia ludzka, co oczywiste, jest strukturą niezwykle złożoną, ale modyfikowalną, poddającą się kreacji także w nowych, nieznanych, a czasami niespodziewanych i osobliwych warunkach. Różnorodne sytuacje pojawiające się w poszczególnych etapach życia nie zawsze tworzą uporządkowany bieg życia. Niekiedy człowiek zmuszany jest do podejmowania takich aktywności, które da- 
lekie są od sprawdzonych, wcześniej wykorzystywanych, wzorów postępowania. To rodzić może zakrzywienie, załamanie linii toru, po którym los jednostki się toczył. Niejednokrotnie skutkuje to uruchomieniem procesu uczenia się, rozumianego jako refleksja, namysł nad dotychczasowym doświadczeniem i własną biografią. Takie uczenie się, choć najczęściej nieuświadomione i nieintencjonalne, bywa zmierzaniem ku pełni człowieczeństwa, ku byciu szczęśliwym (Dubas, 2007, s. 58).

\section{Literatura}

Dobrowolska D., 1992, Przebieg życia, fazy, wydarzenia, „Kultura i Społeczeństwo”, T. 36, nr 2, s. $75-85$

Dubas E., 2007, Wokót paradygmatu uniwersalności w edukacji dorosłych, [w:] E. Dubas (red.), Uniwersalne problemy andragogiki i gerontologii, Wydawnictwo Uniwersytetu Łódzkiego, Łódź, s. 41-63.

Giza A., 1990, Biografia jako fakt empiryczny i jako kategoria teoretyczna, [w:] J. Włodarek, M. Ziółkowski (red.), Metoda biograficzna w socjologii, PWN, Warszawa.

Lindyberg I., 2012, Świat(y) „,upośledzonego” macierzyństwa, Oficyna Wydawnicza Impuls, Kraków.

Mazurek E., 2011, Biograficzne uczenie się kobiety doświadczającej choroby nowotworowej piersi $w$ świetle teorii andragogicznych, [w:] E. Dubas, W. Świtalski (red.), Biografia i badanie biografii, T. 1, Uczenie się z (własnej) biografii, Wydawnictwo Uniwersytetu Łódzkiego, Łódź, s. $51-68$.

Mazurek E., 2013, Biografie edukacyjne kobiet dotkniętych rakiem piersi, Oficyna Wydawnicza Politechniki Wrocławskiej, Wrocław.

Nowak-Dziemianowicz M., 2006, Doświadczenia rodzinne w narracjach: interpretacje sensów i znaczeń, Wydawnictwo Naukowe Dolnośląskiej Szkoły Wyższej Edukacji TWP, Wrocław.

Okła W., 2009, Człowiek w sytuacji choroby, [w:] S. Steuden, K. Janowski (red.), Psychologiczne konteksty doświadczania straty, Wydawnictwo KUL, Lublin, s. 13-23.

Popielski K., 2008, Psychologia egzystencji: wartości w życiu, Wydawnictwo KUL, Lublin.

Prawda M., 1989, Biograficzne odtwarzanie rzeczywistości (O koncepcji badań biograficznych Fritza Schütze), „Studia Socjologiczne”, nr 4, s. 81-98.

Przetacznik-Gierowska M., 2002, Psychologia rozwoju człowieka, Wydawnictwo Naukowe PWN, Warszawa.

Riemann G., Schütze F., 1992, „, Trajektoria” jako podstawowa koncepcja teoretyczna w analizach cierpienia i bezładnych procesów społecznych, „Kultura i Społeczeństwo”, nr 2, s. 89-109.

Schütze F., 1997, Trajektorie cierpienia jako przedmiot badań socjologii interpretatywnej, „Studia Socjologiczne", nr 1, s. 25.

Sobol E. (red.), 2002, Słownik wyrazów obcych, Wydawnictwo Naukowe PWN, Warszawa, s. 1120.

Zakrzewska-Manterys E., 1995, Down i zespół wątpliwości. Studium z socjologii cierpienia, Wydawnictwo Semper, Warszawa. 